\title{
ASSESSMENT OF THE FEASIBILITY TO IMPROVE BUSINESS INCUBATION PROCESSES
}

\author{
Asta FominienE் ${ }^{1}$, ViktoriJa GrigaitienĖ² \\ Vilnius University (Lithuania)
}

\begin{abstract}
As competition is becoming more and more pronounced, the market entry for newly established companies is a complex task. This process becomes even more complicated if a company is small, because it has to deal not only with lack of experience, but also with a lack of funds. Business incubators have been spreading all over the world for more than half a century. It suggests that this type of sponsorship of small and medium business will be relevant in the next decade and continuous research in this field will help to provide optimal support for companies.

KEYWORDS: small and medium business, business incubators, business incubation processes.
\end{abstract}

JEL CODES: $M 10, M 13$

\section{Introduction}

Despite the fact that over the past two decades business incubation processes have been extensively studied by numerous foreign authors, however, in Lithuania this field of research has not attracted much attention and there are only few scientific publications.

A. Fominiene (2010) evaluated the processes of business incubation and identified improvement capabilities for business incubators (proposed the possible classification of business incubators according to the level of development). The study showed that after 10 years of activity all Lithuanian business incubators can be attributed only to the first generation type of business incubators, which activities are focused on the rent of premises and equipment or office services for newly established enterprises. For this reason, it is necessary to create favourable conditions to the Lithuanian business incubators to evolve to the next generation incubators, which could offer a wider spectrum of development opportunities for business. J. Karalevičienè and L. Kušleikienè (2011) conducted a study with an objective to analyse the peculiarities of business incubation in Lithuania. A. Fominiene and J. Mackevičius (2012) examined the definitions which are encountered in different scientific sources and concluded that business incubators can be defined as organizations that provide comprehensive support for newly created or still emerging enterprises and which facilitate their successful development and integration into the competitive market. Moreover, these authors proposed the financial indicators system for the assessment of business incubators performance. M. Kučinskienè and A. Fominienè (2015) analysed public services for business which included business incubation and the com-

1 Asta Fominienè - Vilnius University, Faculty of Economics, Business Department

Scientific interest: SME, support of business, international business

E-mail: asta.fominiene@ef.vu.lt

2 Viktorija Grigaitienè - Vilnius University, Faculty of Economics, Business Department

Scientific interest: business incubation, business processes

E-mail: viktorija.grigaitiene@ef.vu.lt 
plex performance measurement methodology. J. Černevičiūtè and R. Strazdas (2014) examined the role of art incubators in the development of system innovations.

A foreign study by J. Brooneel, T. Ratihno, B. Clarysse, and A. Groen (2011) suggested a classification of business incubators into three groups depending on their provided services. D. Patton, L. Warren, and D. Bream (2009) conducted a study in which they investigated the key factors that promote a successful incubation in the technological business incubators, although S. Stephens and G. Onofrei (2012) claim that the evaluation of business incubation processes by tangible indicators is not entirely complete. The authors introduced their methodology which is focused on the analysis of two types of indicators: "hard measures" and "soft measures". Assessment criteria which can be strictly measured are assigned to hard measures (i.e., provided space, profitability or pace of development), whereas not "clearly" defined criteria or hardly measurable parameters are assigned to soft measures (i.e., skills, confidence or professionalism).

The problem of the research. In 2005 there were 7 business incubators in Lithuania, however, to this day only four of them have been still operating. Therefore, research in this field is relevant. In order to ensure the smooth development of business incubators we have to investigate business incubation processes, the quality of provided services and their practical benefit to the incubated companies and to see the opportunities for the process improvement.

The purpose of this paper is to assess the feasibility to improve business incubation processes in Lithuania.

The methods of the research: systematic and comparative analysis of scientific literature, data collection using questionnaires for interviewing the heads of business incubators and incubating firms.

\section{The theoretical background of business incubation processes}

Business processes are the sum of all performed steps or tasks that provides a particular product or service to the market. The improvement of processes is a logical sequence of tasks, which includes the identification of processes, analysis and development (Holtzman, 2011). There are a lot of articles related to the development of business processes, however, none of them offers a consistent improvement methodology. For the improvement of business incubation processes we have to take into account the incubator's specific goals. Furthermore, each process of the incubator (services) must be evaluated based on the individual scale.

In order to determine the opportunities for the improvement of business incubators, it is necessary to identify the key processes, which have the major influence on the incubator's performance. A successfully operating business is the product of business incubator, however, the self-maintenance is also an important issue for every business incubator. Therefore, the same models of process architecture used for the usual enterprise can be applied for the business incubator as well. On the other hand, the incubator's processes can be seen as the value chain framework. M. Jones (2010) points out that an innovative value-chain model allows to link all the processes into one incubation cycle.

The incubation process usually begins from the establishment of a company and ends when the company is able to operate independently. It must be noted that, in spite of the fact that different scientific papers (Fominienè, Kučinskienè, 2010a; Manan, 2000; Benchmarking of Business Incubators, 2002; Jones, 2010) describe incubation slightly differently, but usually all the processes can be divided into three stages:

1. Pre-incubation. At this stage it is important to ensure the proper selection of companies which are going to be incubated. The uniqueness of business idea, growth prospects, and the innovation must be evaluated.

2. Incubation (classical incubation). This stage lasts for three years and provides funding, mentoring services as well as all types of training. The business incubator must ensure the cooperation, support, and active participation of the companies in the incubation process. 
3. Development stage (after incubation). This step is related to the activities that are carried out when the company reaches a mature stage (leaves the business incubator) and is ready to operate independently. Classical incubation is complete after reaching the objectives or after the expiry of the funding.

In our case, it is appropriate to state that if an enterprise is the product of the business incubator, then all business incubator's services can be treated as the incubating processes. In the literature (Kučinskienè, Fominienè, 2010a; Деменко, 2013; Сартисон, 2013) incubating processes are widely examined and can be divided differently. To summarise, it is reasonable to divide all business incubators' services into three groups: 1) services which help to reduce expenses for a company; 2) consulting and training services; 3 ) assistance in establishing business relations. It is worth to emphasise, that in order to achieve the optimal performance of a business incubator it is necessary to balance all the services for the synergistic effect.

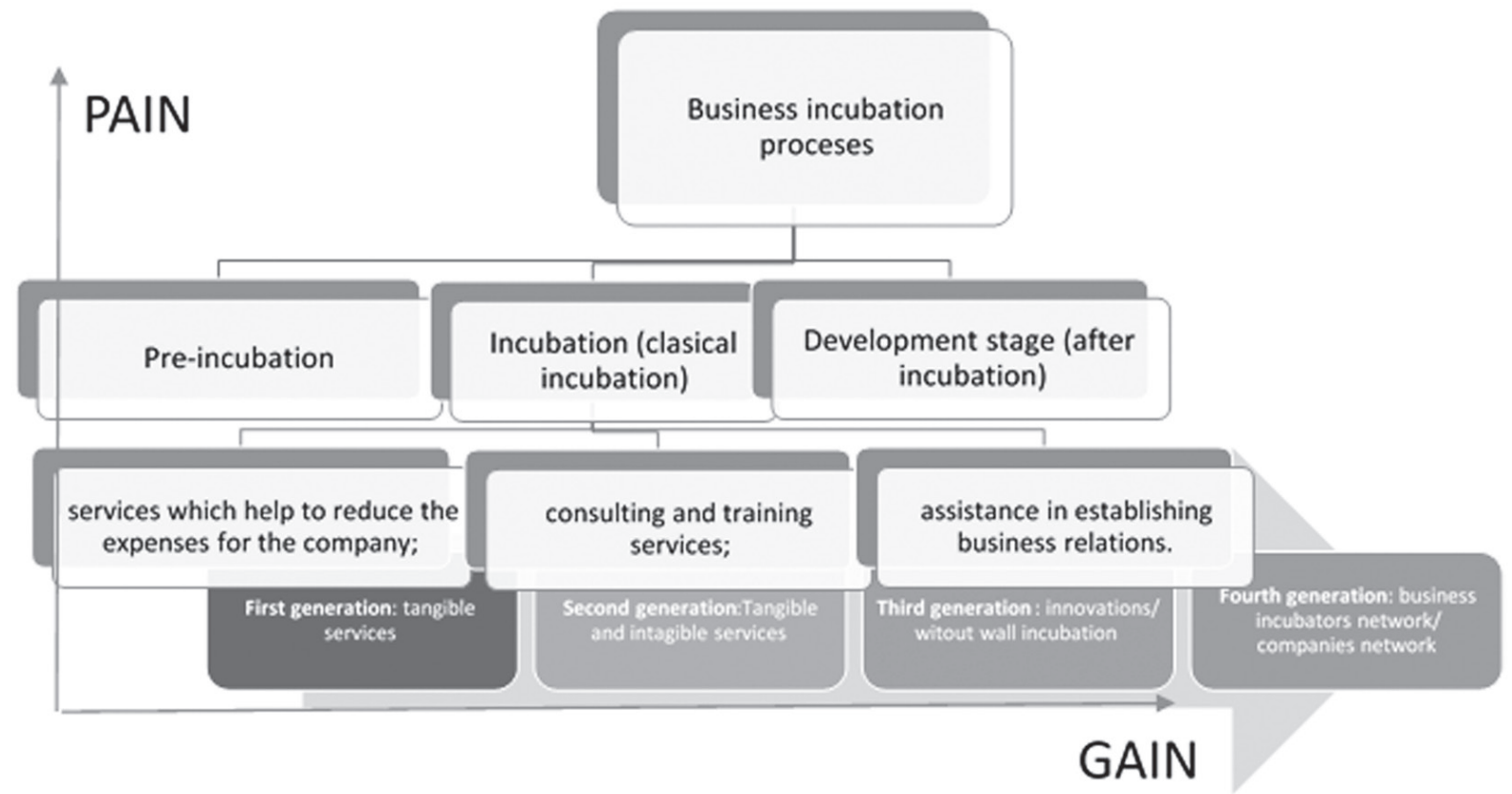

Figure 1. The model for improvement and assessment of business incubation processes

In this study the authors suggest the business incubation assessment model. All the processes are presented as a consistent process chain which is divided into the three main groups (Figure 1):

1) Pre-incubation processes: enterprise selection, trainings, business planning, and market research.

2) Incubation processes: consulting, office and/or equipment rent, entrepreneurship training, innovation for development, financing search assistance, virtual incubation, and the formation of the bonds with other companies and/or business incubators. Rarely business incubator provides all of these services, therefore, depending on the provided services we can estimate the transformation (growth) level of the incubator. This model for the classification of business incubators is based on the transformation model (Fominienè, 2010), which emphasises that the degree of development of business incubators depends on the complexity of the provided services. In our suggested model business incubators of the first generation provide only material services (usually rental services). If a business incubator also provides non-material support (i.e., consulting, entrepreneurial training, financing search assistance) then it can be classified as the second generation business incubator. The incubators of the third generation type are focused on specialised activities like innovation for development or virtual incubation. The fourth generation type incubators, in addition to the above mentioned services, are characterised by the ability to build business relationships among different companies or incubators ("Networking"). According to many authors (Tse, 2002; Freel, 2003) the networking is the main criterion which determines the success of business incubators and incubated companies. 
3) Development stage processes: consulting of the companies which have already left the business incubator.

The evaluation of the above mentioned business incubation processes were carried out according to the "Pain-Gain" methodology developed by R. T. Burlton (2013). All the processes were assessed according to their position in the "Pain-Gain" graph. The processes marked in the right part of the diagram are the most important for the business incubator and the ordinate axis shows how well these processes are performed.

\section{Evaluation of the incubating processes}

In 2015 there were four business incubators in Lithuania: Šiauliai, Telšiai, Kazlų Rūda, and Ignalina business incubators. According to the Small and Medium Enterprises Development Strategy (2015) since the establishment of business incubators until 2015 more than 870 companies were incubated and 3409 new jobs were created in Lithuania. The largest number of created jobs per employee in a business incubator were observed in the business incubator of Telšiai (17 new jobs per one staff member).The data of this strategy also shows that in 2015 the largest number of enterprises were incubated in Šiauliai business incubator (55 companies), and the least in Kazlų Rūda incubator (9 companies).

It should be noted that there is no single methodology for evaluation of business incubator performance. However, there is a comprehensive performance assessment methodology which can be applied to the public administration institutions of Lithuania. It consists of three parts: 1) monitoring of the applied quality management methods; 2) quantitative performance indicators; 3) customers satisfaction index of public services. Yet M. Kučinskienė and A. Fominienè (2015) point out that public services are highly differentiated so in order to improve customer satisfaction it is appropriate to carry out additional studies which could allow adapting the performance measurement methodology to different public organizations.

\section{Research methodology}

In order to evaluate the possibilities to improve the incubation processes, the "Pain-Gain" model (Burlton, 2013) was applied. For this purpose a new methodology was proposed which includes interviews with the managers of business incubators and the survey of incubated companies. The qualitative research was carried out by interviewing all four managers of business incubators. The objectives of the study were to establish standards used for the evaluation of performance indicators and to identify the main business incubating processes as well as their impact on the business.

Research methods: qualitative research (interview) and quantitative research (survey).

Sampling. For the qualitative research the managers of all four business incubators were interviewed. At the day of the study 122 companies were incubated and it was planned to interview the managers of 93 incubating enterprises. The managers of 68 enterprises answered to the survey and the sampling error rate was $6.8 \%$.

\section{Results of qualitative research}

In accordance to the proposed complex performance measurement methodology it was planned to determine how it was applied in the business incubators. The interviews with managers revealed that none of them was participating in the monitoring studies of the application of quality management methods in the Lithuanian public institutions/agencies. None of these methods were used in business incubators as well. Respondents claimed that the main obstacles for the application of the quality management methods were insufficient resources and the lack of staff skills.

Customer satisfaction index of the public services was not calculated. Half of the managers (2) indicated that they were not familiar with this technique. Other two managers claimed that they had not been using these techniques due to the absence of a clear methodology. 
Previously there were some attempts to develop a single methodology for the evaluation of the incubators' performance, however, calculations have not been carried out so far. Usually the incubator's annual report consists of some irrelevant indicators (number of employees, income, number of incubated companies, number of newly created jobs, etc.). In this study, the managers of business incubators were asked to rate on a scale from 1 to 5 how some of the annual report's indicators reflected the real performance of a business incubator (where 1 meant 'does not reflect'; 2 - 'poorly reflects'; 3- 'hard to say'; 4- 'partly reflects'; 5- 'fully reflects'). Based on the results, all indicators can be divided into three groups (see Table 1).

Table 1. The importance of evaluation criteria (according to the managers of incubators) in 2015

\begin{tabular}{|c|c|c|}
\hline & Importance & \multirow{5}{*}{ Very important } \\
\hline Number of consultations & \multirow{4}{*}{4.75} & \\
\hline Number of incubating companies & & \\
\hline Volume of work with incubated companies & & \\
\hline Volume of work with not incubated companies & & \\
\hline Number of companies established with incubators' assistance & \multirow[b]{2}{*}{4.5} & \multirow{7}{*}{ Important } \\
\hline Number of previously incubated companies & & \\
\hline Number of jobs created & \multirow[b]{5}{*}{4.25} & \\
\hline Volume of trainings & & \\
\hline Distribution of entrepreneurship information & & \\
\hline Working with regional education institutions & & \\
\hline Survival rate of previously incubated companies & & \\
\hline Survival rate of currently incubating companies & \multirow[b]{2}{*}{4} & \multirow{5}{*}{ Less important } \\
\hline Percentage of rent occupancy & & \\
\hline Companies' investments & 3.5 & \\
\hline Income & \multirow[b]{2}{*}{3.25} & \\
\hline Number of employees & & \\
\hline
\end{tabular}

As can be seen from Table 1, the most important criteria that reflect the actual performance of the incubator can be considered as "incubator's activities" (for example, the number of consultations, the amount of work with companies or the volume of training). On the other hand, the company's evaluation criteria such as investments, survival rate or paid taxes are considered less important. It is also important to distinguish two other indicators: the number of incubator's employees and occupancy rate. The latter two indicators were rated as not so important, however, they make direct influence on incubator performance. This distribution suggests that Lithuanian business incubators are focused on work with companies, rather than on the results. This may indicate that Lithuanian business incubators can be attributed to the lower type of business incubators.

\section{Results of quantitative research}

Business incubation processes were assessed according to R. T. Burlton's (2013) "Pain-Gain" methodology. The respondents were asked to evaluate the importance and quality of the incubator's processes (services). The services were divided into three groups according to their importance and impact on the development of enterprises. These groups were linked with different types of incubators (see Figure 1). Tangible services are related to a business incubator of the first type. In the "Pain-Gain" diagram they are marked as circles (see Figure 2). Processes which were assigned to the second type incubators are indicated as rhombuses, and business incubators of the third and fourth type are marked as stars. 


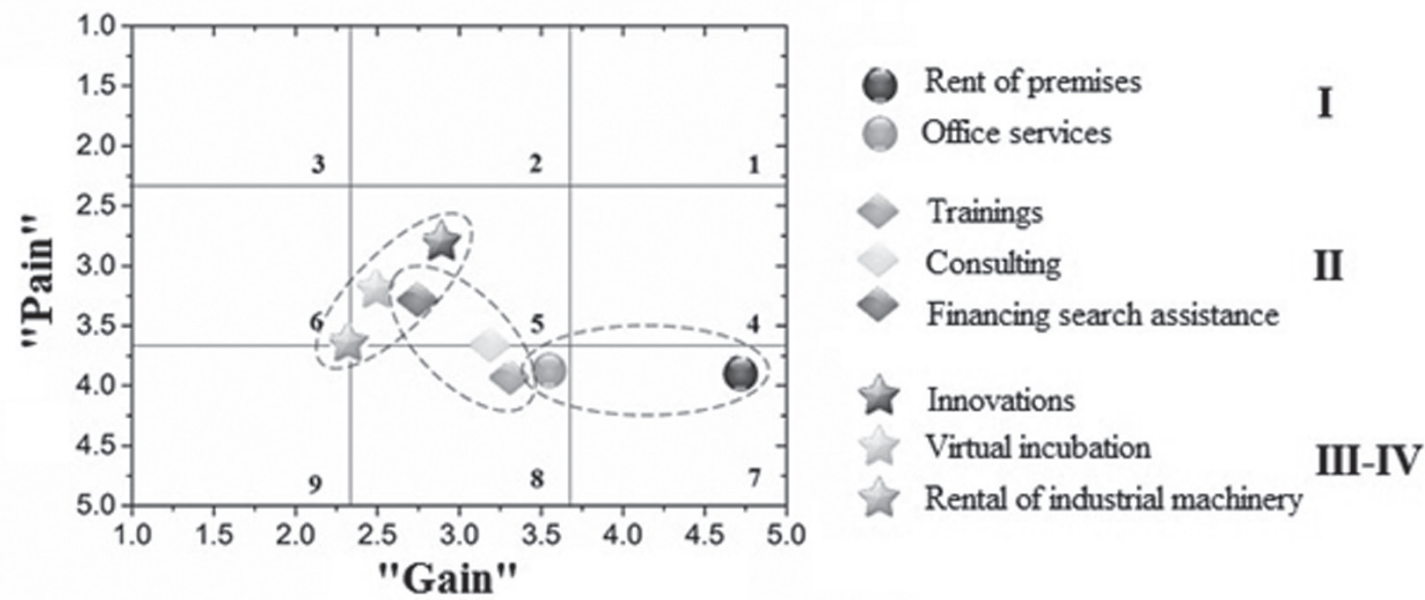

Figure 2. Assessment of incubation processes according to the "Pain-Gain" methodology

As can be seen from Figure 2, the most important processes for the respondents were tangible services, namely, rental of premises and office services. Moreover, according to their quality these services were also considered among the best ones. In fact, it signals that business incubators' activities are not sufficiently developed and business incubators activities are targeted to the basic services. There exists a perception that material help is the most important for their development, however, such service does not substantially increase the added value of the incubated companies.

The respondents indicated that the processes of type III and the financing search assistance are the least important. However, it should be emphasised that this situation is unfair, because these services in the longterm will enable these companies to compete in the market and survive after the incubation process.

The processes marked in squares numbered 1,2, 4, and 5 can be improved, because they are important to the companies though poorly implemented (Figure 2). The highest priority for the improvement must be given to the processes in the first section, the lowest- in the fifth. Thus three processes (financing search assistance, virtual incubation, and innovation) fall into the square 5. It demonstrates that these processes can be improved, though there are no major gaps in the performance. To give an illustration, none of the investigated incubation process quality was assessed as bad or very bad. On the other hand, it should be noted that this methodology assesses processes from the perspective of incubated companies while the point of view of an innovative company may vary significantly. Such concerns might be strengthened by the fact that the selection criteria for companies to enter the business incubator are low.

It is obvious in the diagram that the important processes are working well and the poorly operating processes are less relevant to the incubated companies. It was also observed in the study that services of a higher type business incubator were used by other companies less frequently. On average, $12.2 \%$ of the companies did not use services which were assigned to the first type business incubators, $35.5 \%$ did not employ the services related to the second type of incubators, and even $55.5 \%$ of the companies did not use services attributed to the third type incubators. Based on the fact that services of the higher type business incubators are rarely in use (or it is not possible to use them), they are poorly implemented and also less important for the incubated companies, it must be concluded that Lithuanian business incubators are attributed to the business incubators of the first (lowest) generation type. This conclusion coincides with the findings of the previous study by A. Fominiene (2010) which means that over the past five years there have not been observed major positive changes.

This study shows that the managers of business incubators and the managers of incubated companies are focused on services which are attributed to business incubators of the first and the second generation 
type. However, these services do not create added value nor help to compete in the market in the long-term perspective.

\section{Conclusions}

1. Based on the analysis of the previous studies a new model for assessment and improvement of the business incubation process was introduced. This model evaluates not only the incubation processes but also the development of a business incubator. This conceptual solution allowed to analyse the processes from the point of view of companies and incubators.

2. The study revealed that business incubators are not subject to a single, clearly defined evaluation methodology of business incubator performance. There are no attempts to use the already developed complex public administration assessment methodology. Annual reports do not fully reflect the performance of business incubators. Therefore, it is necessary to design a new methodology for the performance evaluation which would be easy to apply.

3. According to the model it was concluded that Lithuanian business incubators can be assigned to the first-generation business incubators, thus the attention must be given to the development of services of the second-type business incubators (trainings, consulting, and financing search assistance). This insight has partially confirmed R. T. Burlton's "Pain-Gain" model which shows that the services of the first-generation business incubators are working well and do not require additional intervention.

4. Is has been noticed that services of the higher type business incubators are less important for incubated companies, therefore, it is recommended to tighten the selection criteria for companies willing to enter the business incubator. The fact that the barrier of the selection criteria is too low was confirmed by the managers of the incubated companies.

\section{References}

Benchmarking of Business Incubators. European Commission Final Report. (2002). Available at: http://www.cses. co.uk/upl/File/Benchmarking-Business-Incubators-main-report-Part-1.pdf

Bruneel, J., Ratinho, T., Clarysse, B., Groen, A. (2011). The Evolution of Business Incubators: Comparing Demand and Supply of Business Incubation Services across Different Incubator Generations. Journal Technovation, Vol. 32, p. 110-121, doi:10.1016/j.technovation.2011.11.003.

Burlton, R. T. (2013). Business Architecture: The Foundation for Business Process Management and Business Analysis. Conference in Lithuania on Business Process Architecture and Analysis. Available at: http://www.vpvp.lt/ pranesimai/01-Business\%20Architecture\%20-\%20Roger\%20T\%20Burlton,\%20BPTrends.pdf

Černevičiūtè, J., Strazdas, R. (2014). Meno inkubatorių vaidmuo plètojant sistemų inovacijas. Coactivity: Philosophy, Communication, Vol. 22, No. 2, p. 126-136, doi:http://dx.doi.org/10.3846/cpc.2014.11.

Freel, M. S. (2003). Sectoral Patterns of Small Firm Innovation, Networking and Proximity. Research Policy, Vol. 32(5), p. 751-770, doi:10.1016/S0048-7333(02)00084.

Fominienè, A. (2010). Verslo inkubatoriu veiklos transformacija: analize ir vertinimas. Daktaro disertacija. Vilniaus universiteto Ekonomikos fakultetas.

Fominienè, A., Mackevičius, J. (2012). Verslo inkubatorių veiklos analizė: teoriniai ir praktiniai aspektai. Tarptautinė mokslinè konferencija „Apskaita, auditas, analizė: mokslas inovacijų ir globalizacijos kontekste“. Mokslo darbai, d. 1. Vilniaus universiteto leidykla, p. 135-146.

Holtzman, Y. (2011). Business Process Improvement and the Tax Department. Journal of Management Development, Vol. 30, No. 1, p. 49-60.

Jones, M. (2010). How to Create an Award Winning Incubator? 9th Annual Conference on Science Based Incubation, Liverpool, United Kingdom, November 17-19.

Karalevičienė, J., Kušleikienė, L. (2011). Verslo inkubavimas ir verslumo skatinimas Lietuvoje. Profesinés studijos: teorija ir praktika, Nr. 8, p. 205-212. Available at: http://pstp.svako.lt/ps08/p205-212.PDF 
Kokybès vadybos metodų taikymo Lietuvos viešojo administravimo ir kitose institucijose / įstaigose stebėsena $2010 \mathrm{~m}$. ataskaita. (2011). Lietuvos Respublikos vidaus reikalu ministerija, p. 57. Available at: < http://vakokybe.vrm.lt/

Kučinskienè, M., Fominienè, A. (2010a). Verslo inkubavimo proceso transformacijos didejjančios konkurencijos sąlygomis. Verslo ir teisés aktualijos, Nr. 5, p. 110-122, doi:10.5200/1822-9530.2010.04.

Kučinskienė, M., Fominienè, A. (2010b). Viešosios paslaugos: verslo inkubavimas. Viešasis sektorius: organizaciju vadyba, Nr. 1-2 (25-26), p. 81-89.

Kučinskienė, M., Fominienè, A. (2015). Kompleksinis požiūris ị viešojo valdymo institucijų veiklos vertinimą. Accounting, Audit, Analysis: Science, Studies and Business Synthesis: International Scientific Conference, Research Papers. Vilnius University Publishing House, p. 151-165.

Lietuvos Respublikos smulkiojo ir vidutinio verslo plètotés strategija Lietuvos Respublikos ūkio ministerija. (2015).

Manan, H. (2000). Technology Business Incubators - Bringing Technology to the Market Place-Malaysia. International Conference on Business Incubation and Technology Innovation, Shanghai. Available at: http://waitro.dti.dk/Publications/Seminars/China2000/manan.htm

Patton, D., Warren, L., Bream, D. (2009). Intangible Elements that Underpin High-tech Business Incubation Processes. Journal of Technology Transfer, Vol. 34 (6), p. 621-636, doi:10.1007/s10961-009-9105-7.

Stephens, S., Onofrei, G. (2012). Measuring Business Incubation Outcomes. An Irish Case Study. The International Journal of Entrepreneurship and Innovation, Vol. 13 (4), p. 277-285, doi:10.5367/ijei.2012.0094.

Tse, E. (2002). Grabber-Holder Dynamics and Network Effects in Technology Innovation. Journal of Economic Dynamics and Control, Vol. 26 (9/10), p. 172-1738, doi:10.1016/S0165-1889(01)00092-6.

Деменко, О. Г. (2013). О бизнес-инкубаторе как элементе инновационной инфраструктуры. Наука и практика РЭУ им. Г. В. Плеханова, Но. 1(9), с. 130-134. Available at: http://www.rea.ru/UserFiles/elka/журнал Наука и практика 1(9).pdf

Сартисон, Е. А. (2013). Бизнес-инкубаторы: понятие и значение для зкономики края. Коллективная монография Издательство Алтайского государственного университета, с. 132-138. Available at: http:// elibrary.asu.ru/xmlui/bitstream/handle/asu/441/book312t.pdf?sequence=3

\title{
VERSLO INKUBAVIMO PROCESŲ TOBULINIMO GALIMYBIU VERTINIMAS
}

\author{
Asta Fominiené, Viktorija Grigaitienė
}

Vilniaus universitetas (Lietuva)

\section{Santrauka}

Veiklą pradedančios įmonès patiria sunkumų verslo pradžioje, todèl smulkiojo ir vidutinio verslo rèmimas išlieka aktualus. Viena tokių paramos formų yra verslo inkubavimas. Pasaulyje šis klausimas gana plačiai nagrinėjamas, tačiau bendra verslo inkubatorių veiklos vertinimo metodika nesukurta. Nors 2005 metais Lietuvoje veikė 7 verslo inkubatoriai, šiuo metu veiklą tęsia tik keturi iš jų, todẻl tyrimai šioje srityje yra aktualūs. Siekiant sklandžios verslo inkubatorių plètros būtina tirti verslo inkubatorių veiklos procesus, teikiamų paslaugų kokybę ir jų praktinę naudą bei įžvelgti verslo inkubavimo procesų tobulinimo galimybes. Straipsnyje pateikiamos verslo inkubavimo stadijos, kurios nagrinejjamos kaip inkubavimo procesai (priešinkubaciniai, inkubaciniai ir poinkubaciniai), juose teikiamos paslaugos inkubuojamiems ūkio subjektams. Atlikus mokslinès literatūros analizę, pateikiamas verslo inkubavimo procesų vertinimo ir tobulinimo modelis, kuriame integruojami verslo inkubaciniai procesai, juose teikiamos paslaugos ir verslo inkubatorių transformacijos stadijos. Minèti procesai vertinami taikant R. T. Burlton (2013) „Pastangų ir naudos“ (ang. Pain - Gain) metodika, išskiriant svarbiausius verslo procesus ir jų tobulinimo galimybės. 
Atlikus tyrimą nustatyta, kad Lietuvoje veikiantys verslo inkubatoriai priskirtini pirmos kartos verslo inkubatoriams, todèl demesys turi būti teikiamas antros kartos verslo inkubatorių paslaugoms tobulinti. Kadangi paslaugos, būdingesnès aukštesnès kartos verslo inkubatoriams, yra mažiau svarbios šiuo metu inkubuojamoms įmonėms, rekomenduojama griežtinti atrankos kriterijus, kurie turètų užtikrinti didesnę pridėtinę vertę kuriančių ịmonių inkubavimą.

PAGRINDINIAI ŽODŽIAI: smulkusis ir vidutinis verslas, verslo inkubatoriai, verslo inkubavimo procesas.

JEL KLASIFIKACIJA: M10, M13 